Portland State University

PDXScholar

$5-25-2019$

\title{
Designing Katana : Unsheathing the Potential of Gameplay for Constructing Cultural Memory
}

Tracy Alan

Portland State University

Follow this and additional works at: https://pdxscholar.library.pdx.edu/honorstheses

Let us know how access to this document benefits you.

\section{Recommended Citation}

Alan, Tracy, "Designing Katana : Unsheathing the Potential of Gameplay for Constructing Cultural Memory" (2019). University Honors Theses. Paper 735.

https://doi.org/10.15760/honors.742

This Thesis is brought to you for free and open access. It has been accepted for inclusion in University Honors Theses by an authorized administrator of PDXScholar. Please contact us if we can make this document more accessible: pdxscholar@pdx.edu. 
HONORS THESIS

\title{
DESIGNING KATANA
}

\author{
Unsheathing the Potential of Gameplay for Constructing Cultural Memory \\ Tracy Alan
}

\begin{abstract}
Players take the role of an ambitious samurai in Katana, a turn-based card game designed to evoke the cultural memory of early modern Japanese warriors. Going beyond token use of history as mere fantasy setting, the game synthesizes historical research, communication design methodologies, and interactive design frameworks to create a compelling experience. The design of Katana is influenced by Jason Begy's concept of cultural memory as a broad interdisciplinary approach to formulations of historical content that intentionally go beyond traditional scholarly modalities such as the publication of monographs and journal articles, archaeological surveys, and lectures. The multivalent interactivity of gameplay generates a unique level of engagement distinct from other forms of communication, providing opportunities to reach new audiences and explore a variety of historical perspectives. Tense, turn-based card play serves to abstract the careful, contemplative nature of samurai combat, but also encourages strategic thinking and role-playing that supports a deeper understanding of historical concepts and cultural experience than other forms of media. Months of research, play-testing, and visual refinement culminated in late May 2019 with the launch of a Kickstarter campaign to acquire funding for mass production of Katana and gauge public interest in games for the construction of cultural memory.
\end{abstract}

University Honors College

Portland State University

24 May 2019 


\section{Introduction}

History has been written since the days of Homer and Herodotus, the passage of time providing us with the benefits of writing and computing technologies to ease the process. Yet, historical discourse typed into a word processor by a modern historian is essentially the same intellectual exercise as Thucydides scratching the history of the Peloponnesian War onto scrolls, which is to say that our methods of historical study have remained consistent for literally thousands of years. While there is something to be said for such consistency, the availability of new media renders devotion to the tradition of written discourse outmoded. Games, in particular, provide a unique opportunity for historical study to break away from purely written discourse with multilayered experiences that engage new perspectives and peoples. The interactivity of games presents opportunities for far richer experiences than possible with the passive consumption of media (reading, watching a movie, etc.) because of the heightened levels of engagement required when playing a game, but also because the emotional responses that occur during play create understanding of historical scenarios difficult to achieve with writing alone.

\subsection{Introduction to Cultural Memory}

Interdisciplinary approaches to historical content summarizes the broad field of cultural memory studies. Objects of study include historical events, material culture, holidays, rituals, formal scholarship-anything relevant to the formation of collective social memory. Jason Begy articulates cultural memory studies as focused on understanding how modern cultures construct their own past and those of other cultures in the present. ${ }^{1}$ Unlike historical discourse that is chiefly concerned with interpreting the past, cultural memory is not fixated as much on what did or did not happen, but how that history is represented today. ${ }^{2}$ This relates cultural memory studies to historical discourse, but it is distinct in its concern for the expression of historical content in the present and how the format of that expression influences consumption of the content. Cultural memory can be thought of as applied history: communication arts are used to engage a variety of audiences with historical content. ${ }^{3}$

Yet, the portrayal of history in games has a checkered past. Historical scenarios are often appropriated as game setting without much intention beyond providing an intriguing façade. Xbox One action title Ryse: Son of Rome is a prime example of this: developer Crytek rendered a stunning digital vision of early imperial Rome, but it is a spectacle light on substance. The streets of Rome are mere visual setting for bloody action, little in the way of historical understanding is achieved aside from recognition of the empire's violent nature; in fact, the

1 Jason Begy, "Board Games and the Construction of Cultural Memory," Games and Culture 12, no. 7-8 (November 2017): 719. "The field of cultural memory studies is concerned with how cultures construct their past, and as such its objects of study include everything from holidays and rituals to media and even formal historiography."

2 Begy, "Board Games and the Construction of Cultural Memory," 720. "The field is not interested in what did or did not happen, but rather how those events are constructed in the present." Begy's phrasing implicates the empiricism of German historian Leopold van Ranke as counter to the interdisciplinary approach of cultural memory studies. Ranke described the aim of the historian is to show what actually happened ("wie es eigentlich gewesen"); however, postmodernists and postcolonial scholars have challenged this viewpoint, as it objectifies history as a knowable, certain, singular thing to be discovered. On the contrary, historical understanding is difficult to achieve, highly qualified, and often conclusions are ambiguous.

${ }^{3}$ Ibid. "Because cultural memory is by definition a shared memory it depends on communicative arts to function." 
game inexplicably edits historical facts such as demoting the Celtic Queen Boudicca to a lesser princess, daughter of a fictive king. While such details may seem trivial, they only highlight the disconnect from historical discourse and experience.

The fictionalization of history is an issue in games and not just from the designer's perspective. The nature of games as an interactive medium provides the right conditions for counterfactual scenarios. These are unintentionally fictive visions of historical experience counter to our understanding of the evidence. In some cases, counterfactuals are troublesome and inhibit comprehension of historical concepts. In Assassin's Creed: Odyssey by Ubisoft, the player is presented with a choice: with the Athenian or Spartan armies lined up face-to-face, you must decide which to join; but, you are free to kill soldiers in either army before making your decision, at which point you are welcomed without any reference to the murders just committed. Such scenarios are laughable and make for good YouTube and streaming content, but they do nothing to cultivate understanding of the lived experience of Greek warriors. This does not mean counterfactuals are without value, as they empower players to engage with historical narratives in ways not possible with passive consumption of scholarship. ${ }^{4}$ The challenge is to facilitate counterfactual engagement that grants some freedom of choice to the player for exploration, but retains enough focus on historical concepts so as to structure the formation of cultural memory.

Other games succeed in accurately portraying historical scenarios, though the extent of simulation creates a steep learning curve that limits engagement. This is particularly true of digital gaming experiences such as Eugen System's World War II real-time strategy game Steel Division: Normandy 44 and Creative Assembly's title Shogun: Total War that treat its historical subject matter with great respect, but the intricacy and complexity of gameplay limits their appeal to all but a devoted community. Table top games (i.e. board, card, dice, and other games with physical materials require to play) frequently exhibit the same quality, the level of commitment required to learn and play titles like Axis \& Allies or Republic of Rome in which games may last several days simply turns off many individuals from what is otherwise rich and well-considered historical gaming.

But, cultural memory is constructed from these experiences irrespective of the quality of historical content provided. ${ }^{5}$ People are forming their own historical narratives, piecing together cultural memories based on the media they consume, which includes games. The opportunity before us requires seizing gameplay as one of many tools available to historians, designers, and others interested in the construction of cultural memory.

\subsection{Thesis}

My research seeks to understand the relationship between game design, historiography, and cultural memory through the act of creating a two-player samurai action card game entitled

\footnotetext{
${ }^{4}$ Begy, "Board Games and the Construction of Cultural Memory," 720. "Although simulations necessarily create counterfactuals by allowing players to alter historical detail (because of their interactivity), they are still valuable in that they allow a deeper conceptualization of history."

${ }^{5}$ Begy, "Board Games and the Construction of Cultural Memory," 736. "...regardless of the theories of those engaged in the debate, the games themselves are out there influencing how players understand the past... cultural memory's influence operates regardless of historical accuracy."
} 
Katana. Specifically, I study how to communicate salient themes in early modern Japanese historiography - the militarized nature of Japanese governance, social ethics amongst samurai called bushido or "way of the warrior," kami devotion-by means of a commercially viable game capable of facilitating emotional engagement, competitive drama, and thoughtprovoking counterfactual scenarios.

By taking an interdisciplinary approach, my desire is to engage new audiences and encourage fresh thinking among scholars by harnessing the interactive modality of game design. To do this, I developed conceptual methodologies that informed the iterative design methods used to produce the game and its printed materials. With clear conceptual frameworks and practical objectives identified, I successfully created a viable game and launched a crowdfunding campaign on Kickstarter to mass produce copies for sale around the globe. While the campaign is ongoing at the time of this publication, early indications imply a positive reception for Katana and more broadly for the concept of games as means for creating and consuming cultural memory.

\section{Conceptual Methodologies}

This project employs a combination of conceptual approaches: cultural memory construction, historiography, and conceptual game design. Cultural memory has previously been discussed 
and corresponds to the formulation of interdisciplinary methodologies. In this project, cultural memory is constructed through hybridization of historiography and interactive design methodologies; however, cultural memory is not limited to this formulation, nor does it require either of these particular approaches. Instead, these modalities-history and game design-made sense for communicating key concepts about early modern Japan in a meaningful way, that is through dramatic gameplay interactions.

\subsection{Historiography of Early Modern Japan}

Historian Charles Holcombe observes samurai were initially bodyguards trained as mounted archers; only in later periods did samurai practice swordsmanship and become entwined with the business of state. ${ }^{6}$ Militias assembled around the Taira and Minamoto families by the eleventh century, which encouraged the formation of a dedicated class of warriors. The uncertainty of imperial politics resulting from the Insei system of cloistered emperors created an opening for the Taira and Minamoto warrior bands to accumulate power. The Gempei War, 1180-85, consolidated the power of Minamoto Yoritomo and introduced the concept of bakufu, or military government ("tent government"). ${ }^{7}$

In 1192, Minamoto Yoritomo was declared seii taishōgun, or "Great General Pacifying the Barbarians"; simply put, he was the first of many shōgun whose power was founded on military force and image of strength. Historian Takeuchi Rizō contextualizes the creation of a warrior class under the seii taishōgun, or supreme general, as operating within a redefined imperial ideology that preserved the executive role of tennō, but deputized functional powers of the state to the shōgun. ${ }^{8}$ Although powerful, Yoritomo and other shōgun did not eliminate the imperial family because of their desire for legitimacy, as well as cultural reverence for a continuous Japanese imperial lineage. This history of military control through bands of samurai provides an intriguing backdrop for the head-to-head sword battles of Katana.

The samurai class were essential not only in defining Japanese military operations and a culture of violence, but also in the genesis of culture: literature, fashion, social etiquette, calligraphy, flower arrangement, and other cultural forms stem from the samurai class of this era. Courage, respect, benevolence, honor, rectitude, honesty, and loyalty - these were the seven virtues of bushido, the code of conduct for the samurai warrior class as articulated by the seventeenth century Zen Buddhist monk Yamaga Sogō. Eric Mulien discerns warrior aesthetics, philosophical outlook, intellectual culture, and ways of life from Sogō's writings, tracing the codification of samurai culture and values over time through succeeding authors

\footnotetext{
${ }^{6}$ Charles Holcombe, A History of East Asia: From the Origins of Civilization to the Twenty-First Century (New York: Cambridge University Press, 2011), 148. “The word samurai originally meant 'attendant,' and in the eighth century, it typically referred literally to household servants. By the early Heian period, the word had begun to be applied to armed household guards in attendance on court nobles. Such private guards had become necessary because of the deteriorating security situation even in the capital."

${ }^{7}$ Holcombe, A History of East Asia: From the Origins of Civilization to the Twenty-First Century (New York: Cambridge University Press, 2011), 150-51.

${ }^{8}$ Takeuchi Rizō, "The Rise of the Warriors," in The Cambridge History of Japan, Donald H. Shively and William H. McCullough eds. (Cambridge: Cambridge University Press, 1999), 708. "Society was fundamentally altered as the warrior gentry of the provinces created a new political structure independent of the imperial court that supported a role for warriors in the administration of land. The court became mostly subservient to the will of Yoritomo, and its economic foundations were much eroded in favor of the warriors. The key relationship in society came to be that between military lord and his kinsmen and retainers."
} 
such as Yagyū Munemori and Katō Kiyomasa. The importance of honor and proper conduct defined samurai identity and relations to a significant extent in and out of battle. ${ }^{9}$ The sword as soul was another concept associated with the samurai, promulgated by shōgun Tokugawa leyasu. ${ }^{10}$ Together, these ideas of honor and swordsmanship characterize the portrayal of samurai in my game Katana. Interactions between players who role-play as samurai are contextualized within a culture of honor that governed violent warfare.

Additionally, the syncretism of Japanese religion saw a blending of native Shinto beliefs with Buddhist doctrine and iconography that was promulgating by the samurai class. ${ }^{11}$ Together, these elements of samurai culture created a unique identify for early modern Japan defined as much by graceful, thoughtful culture and aggressive, self-aggrandizing violence. Rizō's portrait of samurai as both violent and cultured informs my own depiction of this intriguing class of warriors in Katana.

\subsection{Conceptual Game Design Methodologies}

Katie Salen and Eric Zimmerman establish a taxonomy of games and framework for study in their formative text, Rules of Play. Salen and Zimmerman define games as systems established by rules that facilitate interaction and competition among players. ${ }^{12}$ Consistent with Johan Huizinga's conception of play as cultural form, ${ }^{13}$ Salen and Zimmerman had cultivated an approach to game design that focuses on creating meaningful play, which occurs when the relationship between actions and outcomes in a game are discernible and integrated into the larger contexts of the game. ${ }^{14}$ Katana supports meaningful play by providing players opportunities to make decisions that have both immediate impact and larger consequence on a player's standing in the game.

While many games primarily exist for the purpose of entertainment, serious games are defined as having objectives other than entertainment: skill instruction and cognitive learning, as two examples. The cognitive-behavioral game design framework articulated by Katryna Starks presents an approach to serious game design that blends entertainment with pedagogic

\footnotetext{
${ }^{9}$ Eric Mulien, "Bushidō-The Way of the Warrior," in Art of Armor: Samurai Armor from the Ann and Gabriel BarbierMueller Museum, Gabriel Barbier-Mueller, ed. (New Haven: Yale University Press, 2012), 111. Bushidō articulated seven virtues: "courage, respect, benevolence, honor, rectitude, honesty, and loyalty."

${ }_{10}$ Mulien, "Bushidō-The Way of the Warrior," in Art of Armor: Samurai Armor from the Ann and Gabriel Barbier-Mueller Museum, Gabriel Barbier-Mueller, ed. (New Haven: Yale University Press, 2012), 116.

${ }^{11}$ Rizō, "The Rise of the Warriors," 663. "Prayer to the guardian deity or a family and the family ancestors was essential."

12 Katie Salen and Eric Zimmerman, Rules of Play: Game Design Fundamentals (Cambridge, MA: MIT Press, 2003), 80. "A game is a system in which players engage in artificial conflict, defined by rules, that results in a quantifiable outcome."

${ }^{13}$ Johan Huizinga, Homo Ludens: A Study of the Play-Element in Culture (Boston: Beacon Press, 1955), 9. In his foundational monography for the field of ludology, Huizinga defines play as a significant function to be understood as a cultural phenomenon. He argues for the universality of play which transcends all forms of material culture and points to a deeper level of cultural interaction. Furthermore, play is performative in that it requires decision-making and action within a defined system of rules. While play is disconnected from reality, "as an intermezzo, an interlude in our daily lives," it is governed by both tacit and explicit rules. In this sense, Huizinga contends, order and logic are created by way of play. Accordingly, play can be a competitive or representative; in other words, the order might be oriented toward a contest or simulation. These forms of play can be mixed in various ways to create different types of experiences. Huizinga's conception of play as a cultural form informs my work to use gameplay as a means to communicate historical concepts. The universality of play ensures broad appeal, whereas the performative aspect facilitates a unique form of engagement with historical concepts of the samurai by way of competitive gaming.

${ }^{14}$ Salen and Zimmerman, Rules of Play, 34. "Meaningful play occurs when the relations between actions and outcomes are discernible and integrated into larger contexts."
} 
content. ${ }^{15}$ Starks defines three pillars for serious game design: social cognitive elements, multiple intelligences, and enjoyment processes. Social cognitive elements relate to five parameters governing the decision-making process: knowledge, goals, outcome expectations, encouragement, and barriers. For example, knowledge might empower a player to take a specific action, but only if the action aligns with stated goals and encouragement exists (this can be in the form of a quantifiable reward or simply social support from other players). Multiple intelligences theory describes different aspect of human intelligence-linguistic, kinesthetic, logical, spatial, etc. - which ought to be catered to maximize accessibility and engagement for a diverse audience. Enjoyment processes are how the previous pillars of the framework are manifest in the game experience. Enjoyment involves engagement, challenge, flow, persistence, and facilitates mastery. Optimal game design affords players a space within its system of rules to become highly engaged by challenging play that rewards persistence and mastery. Flow indicates the extent to which players are absorbed in the experience, which singularly can be used to measure the success of a given game system in relation to learning outcomes and enjoyment.

\section{Practical Methodologies}

\subsection{Interaction Design Methodology}

Achieving meaningful play requires an iterative design methodology. Cycling through this process enables incremental change to design to address specific mechanics so as to move closer to meaningful play. Moreover, iteration is essential for effective evaluation of game design, as the system of rules may result in unexpected interactions.

${ }^{15}$ Katryna Starks, "Cognitive Behavioral Game Design: A Unified Model for Designing Serious Games," Frontiers in Psychology 5 (2014): 9. "Conventional education involves a form of passivity for students in that they are often expected to be quiet learners who simply absorb the content introduced by the teacher. However, the interactivity of game environments allow for the use Howard Gardner's expanded learning theory which involves the multiple intelligences: logical/mathematical, musical, body/kinesthetic, and linguistic." 
Steve Krug's volume on user experience design is applicable given my objective of meaningful interaction. Chiefly, Krug advises prioritizing the user experience in design so as to create useable experiences. To achieve this, frequent and focused user testing is required. Confronting the common belief that user testing requires a large focus group and formality, Krug encourages quick and dirty testing with small groups to identify two or three issues with the design that can reasonably be addressed. With this feedback, a new iteration of the design can be created and tested to determine if the identified issues are solved, need additional attention, or if new problems appear. Extending from Salen and Zimmerman's iterative methodology for meaningful game design, Krug provides an approachable process for playtesting and refinement that has been instrumental in my design of Katana.

Playtesting of Katana began the first day of design. A simple prototype deck of cards was crafted using a deck of playing cards and sticky notes. While unattractive, the deck was suited for the temporary function of testing initial concepts. Once I established functional mechanics and a firmer sense of rules, I widened my testing to include individuals unfamiliar with the game. Both formal and informal tests were done when possible over an 18-month period, each providing insight into player behavior, efficacy of the game design, and more.

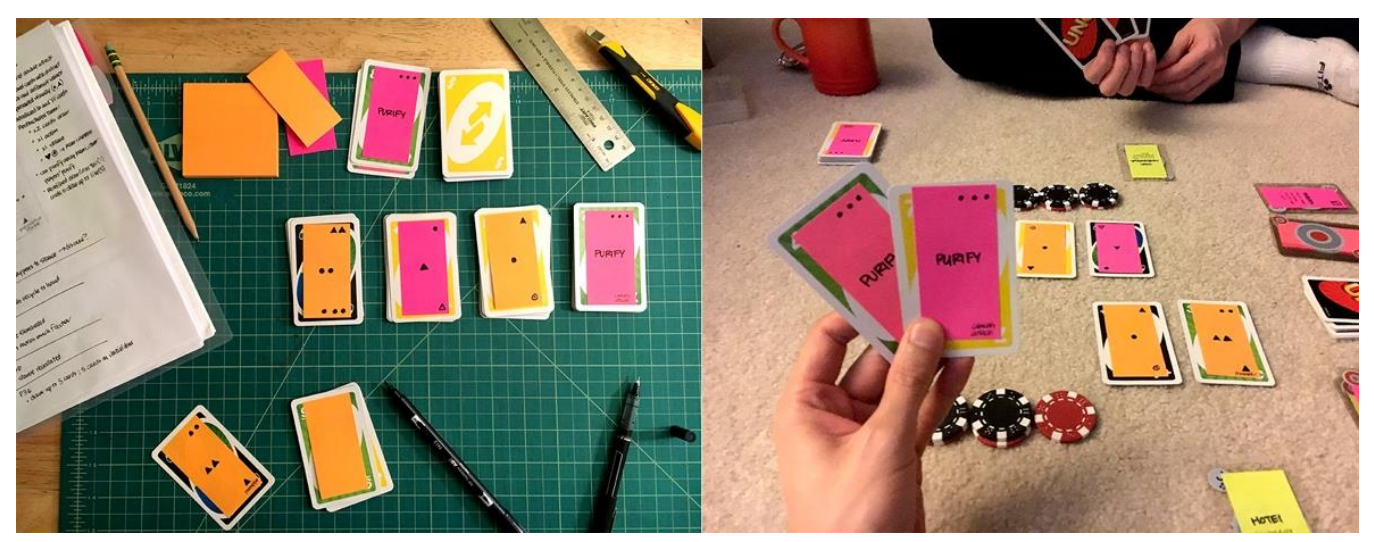

Figure 1-Early Prototype for Katana 


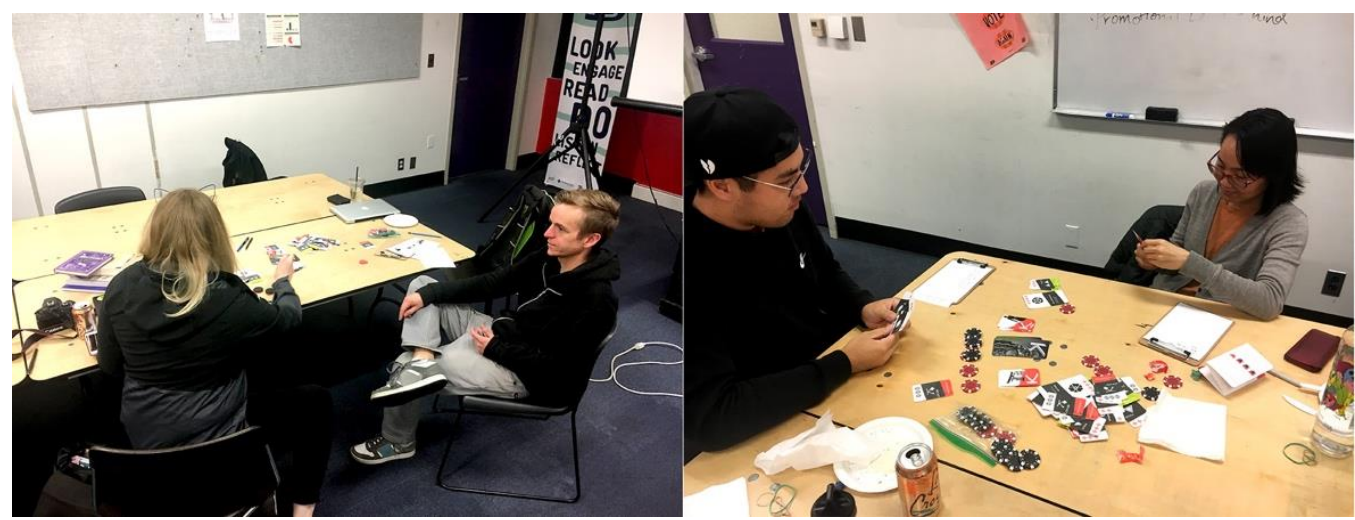

Figure 2-Playtesting Katana at Portland State University School of Art and Design, October 2018

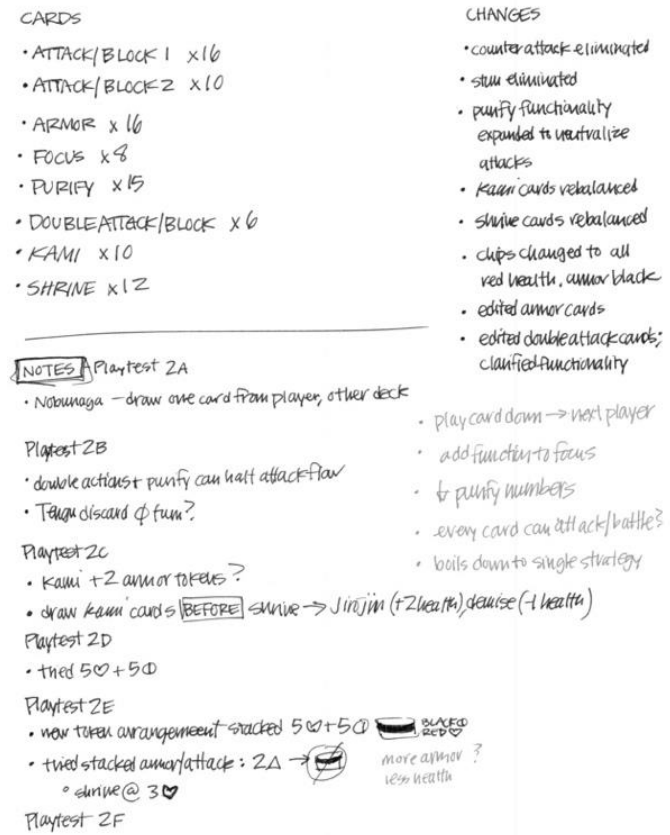

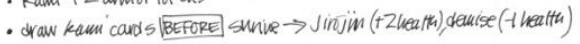

CHANGES

- counter attack elimingted

- stun eliminated

- punfy funchionality

expansed to veutvalize

atlacks

- kacuicards vebalanced

- sunive cards rebalanced

- chips changed to all

red hearth, amor black

- edited amer cards

- edited doubleattack cands:

clanfied functionality

- playcard down $\rightarrow$ next played

- add functinto fous

- \& punfy numbers

every card can att ack/battle?

ooils down to single strategy

anmor?

Maptest $2 F$

Figure 3-Selected Katana Playtesting Notes

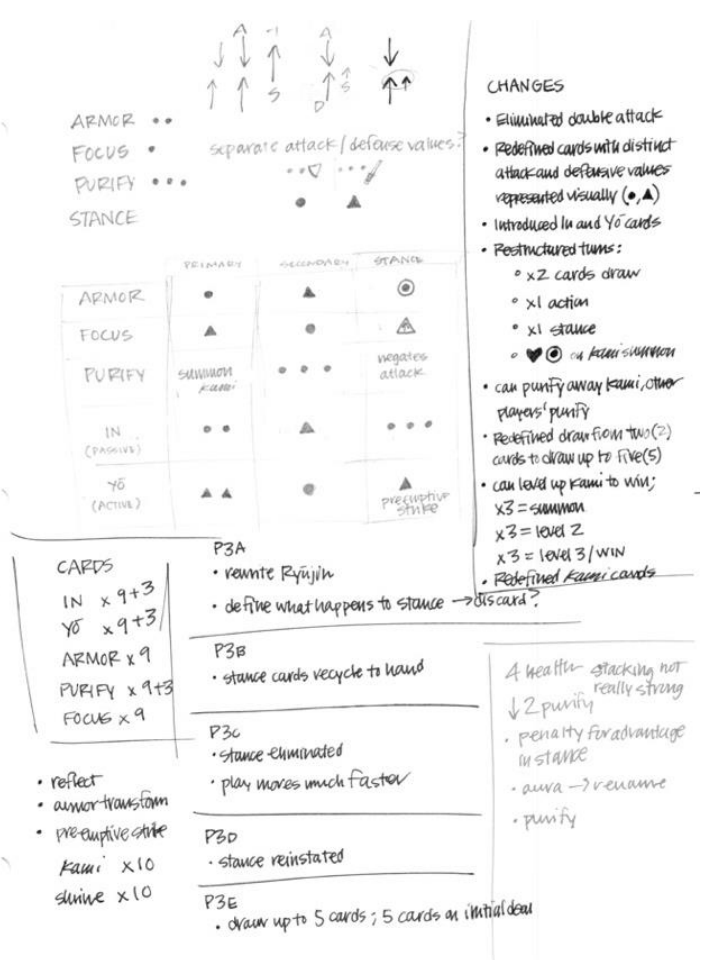




\subsection{Visual Design Methodology}

Design methodology for this project-both interactive and visual-was iterative. The process is defined by an initial ideation and research process. Next, design directions are identified; mood boards, wireframes, and concept statements crafted. From these materials, thumbnail sketches of game materials and Kickstarter campaign materials design, digital mocks up then drafted based on selected sketches before moving onto production of the final work.

\section{RESEARCH $\rightarrow$ IDEATION $\rightarrow$ CONCEPTUALIZATION \\ FINAL PRODUCTION « DIGITAL ROUGHS ↔-SKETCHES}

This process was used to produce everything for Katana from its logo and website to the cards and packaging. However, as the game's visual identity took shape with each graphic component completed, the work of generating new visuals became easier. The challenge at that stage was twofold: to keep the graphic design varied and fresh, while at the same time create a sense of visual unity and brand cohesion. Given these seemingly conflicting goals, decisions regarding color, shape, texture, and layout were carefully considered not just in terms of an individual item or design, but as part of a larger system. Items designed include: action deck, kami deck, shrine deck, health and armor tokens, packaging, logo and branding system, a dedicated website, a video trailer, and marketing collateral such as posters.

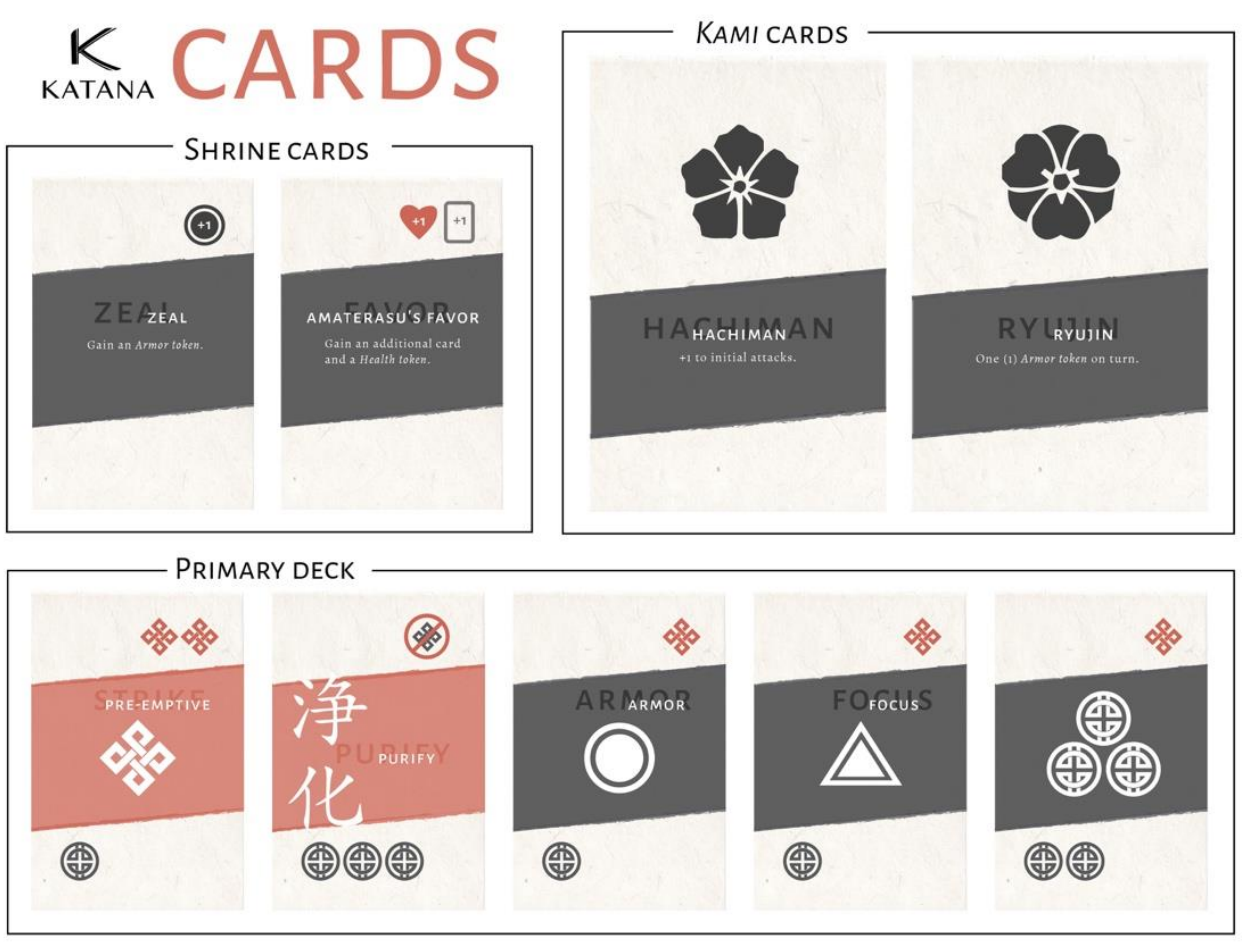

Figure 4-First Visual Direction for Katana 

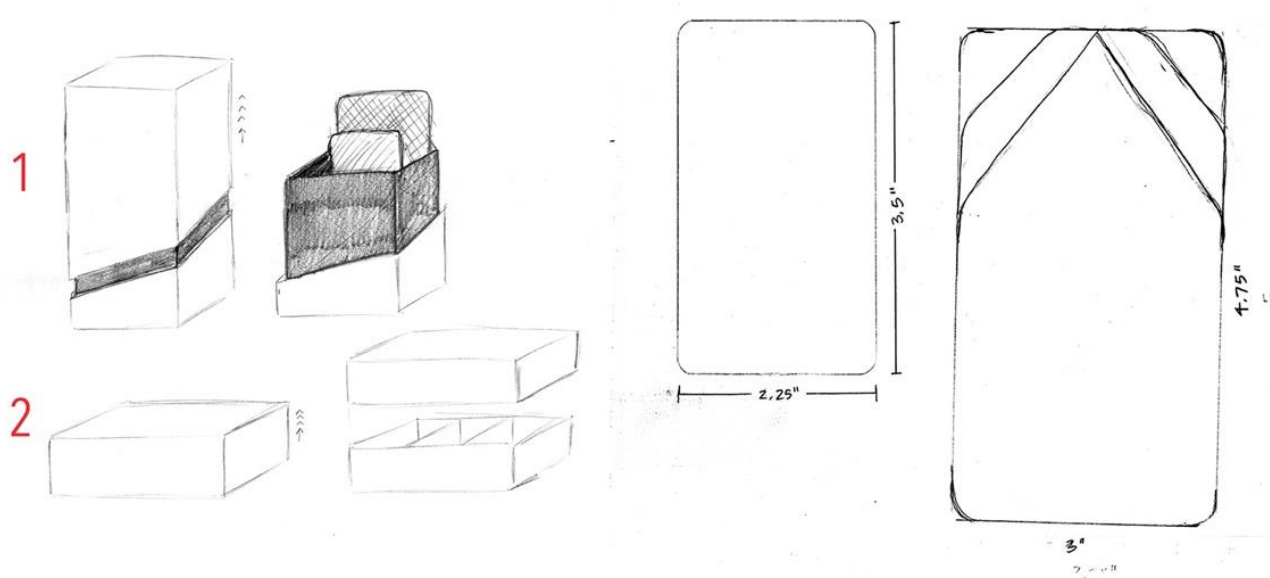

Figure 5-Packaging and Card Sketches

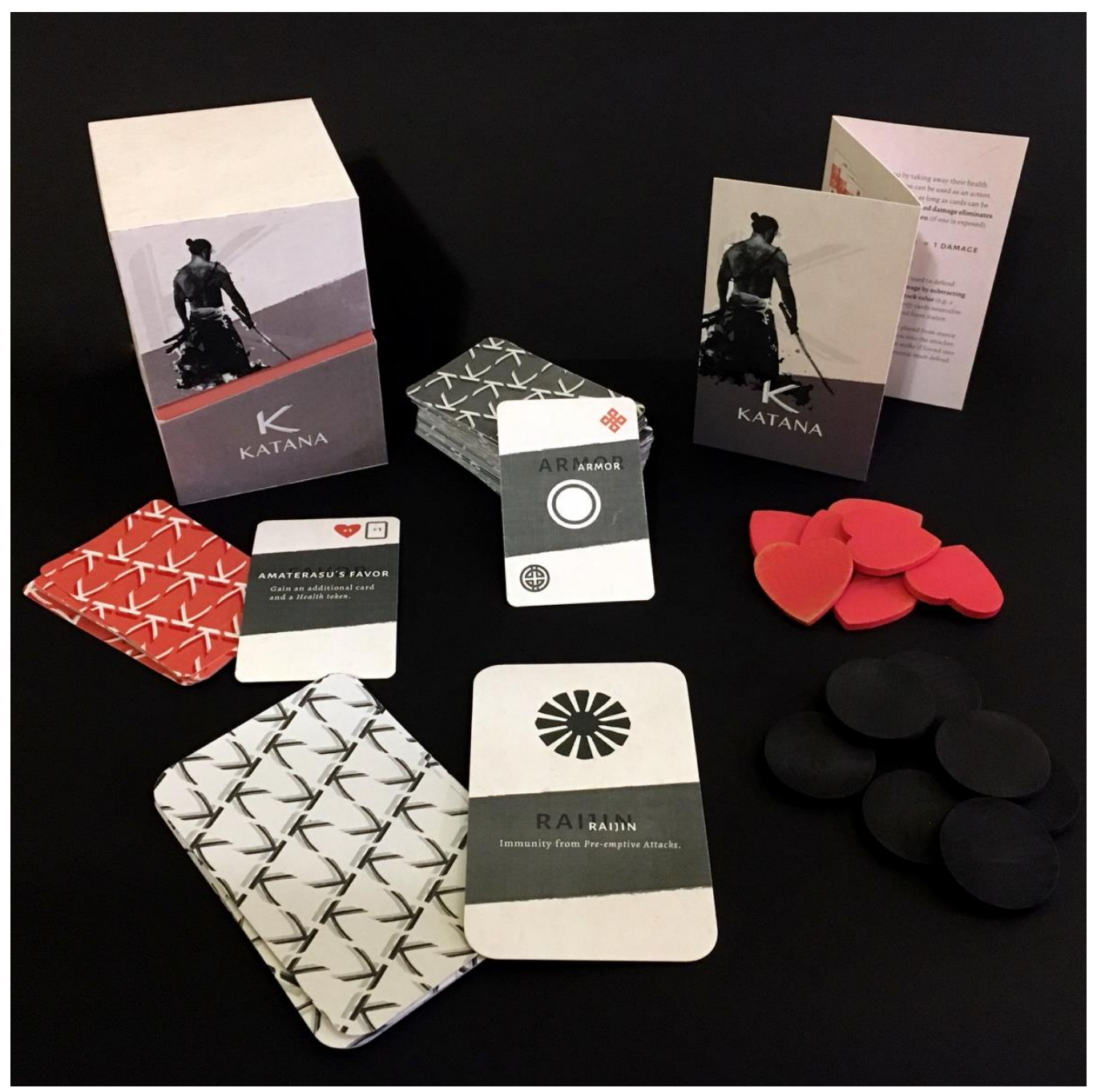

Figure 4-First Complete Version of Katana 


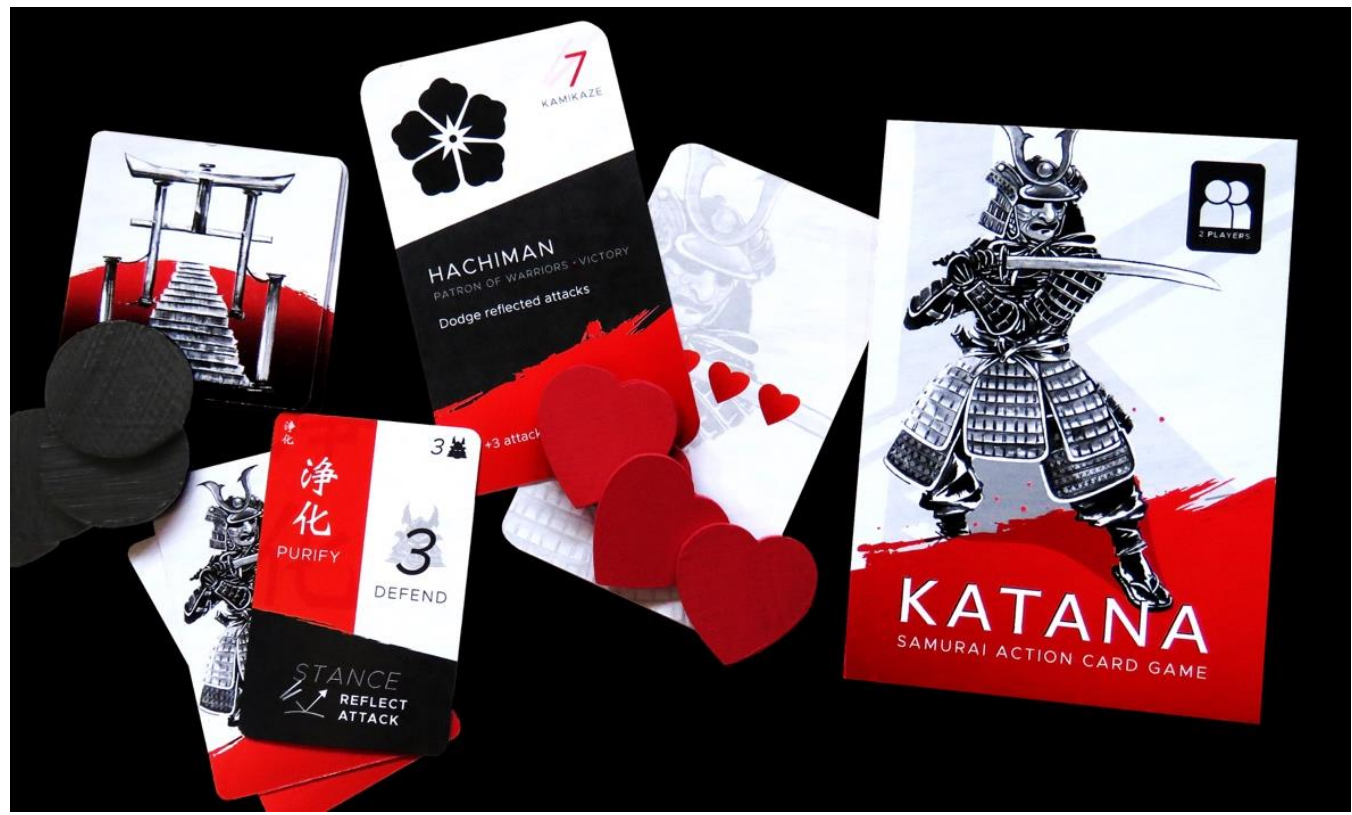

Figure 5-Final Version of Katana

\section{Praxis}

\subsection{The Construction of Cultural Memory in Katana}

Katana is designed to communicate historical concepts related to early modern Japanese warrior culture. At its most basic level, it is a two-player turn-based card game in which players fight to become shōgun of Japan using cards to attack, defend, counter, and even reflect damage. Players battle until they run out of armor and health tokens symbolic of material reality. Additionally, supernatural creatures called kami possessing tide-turning powers can be activated through ritual purification cards. These mechanics are designed with an awareness of early modern Japanese historiography and sensitivity to the experiential components of gameplay as a mechanism by which historical experience can be emulated. This occurs on three distinct levels in Katana, explained in detailed below: representation of early modern Japanese political concepts and structures, the mechanics and experience of one-on-one combat, and the ubiquitous nature of Shinto spirituality to early modern Japanese interpretation of their world.

\subsubsection{Mapping Historical Concepts to Game Setting and Mechanics}

Historiographical concepts are mapped to the design for the purpose of illustrating setting and providing meaningful interaction. Wielding katana was a marker of socio-political power, as much as it was a representation of military power given that swords were privileged arms of an elite land-owning class. ${ }^{16}$ In this way, Katana reflects the basic socio-political structure of early modern Japan with a setting focused on samurai battling with swords available

\footnotetext{
${ }^{16}$ John Stevenson, "The Warrior in Japanese History," in Art of Armor: Samurai Armor from the Ann and Gabriel BarbierMueller Museum. Gabriel Barbier-Mueller, ed. (New Haven: Yale University Press, 2012), 44.
} 
specifically to a privileged warrior class capable of affording them. ${ }^{17}$ Furthermore, the focus on swordsmanship situates the game no earlier than the Muromachi period, as before this era samurai primarily focused on archery and were mounted warriors. ${ }^{18}$

Another early modern Japanese political institution, the shōgun, features prominently as the incentive for victory in Katana. This grand reward for defeating rival samurai is not hyperbole for the sake of dramatic gameplay, but a reflection of lived historical experience. Samurai fought each other for domination; martial power, leadership, and cleverness determined the leader of the pack. Yet, samurai did not vie to become emperor. Unlike other monarchical societies in which dynasties compete for supremacy over time, Japan maintained a single royal lineage that remained intact in the era of tent government. ${ }^{19}$ Accordingly, players of Katana do not endeavor to become emperor, but rather shōgun.

\subsubsection{Abstracting Combat}

There are two ways in which Katana abstracts samurai combat with respect to historical evidence: first, in the direct mapping of combat tactics to card mechanics, and second, in the strategic considerations demanded of players by turn-based mechanics in which future moves and an opponent's possible actions must be considered carefully.

Cards were chosen to relate the tactile nature of wielding katana. The action deck used for combat features attack and defend abilities; combat is a matter of an attacker playing an action card, the value of which is subtracted from whatever card played by the defender. The resulting value determines the armor and health tokens lost, if any. Health tokens are only lost after the armor tokens stacked upon them have first been shattered in combat, alluding to the function of ornate samurai armor comprised of lacquered plates, silken robes, and elaborate helmets. The game acknowledges the kinesthetic aspects of samurai combat training by introducing stance mode. At the end of each turn, a player must set their stance by playing a card face down. This card activates during their opponent's turn, acting as a sort of second, delayed action. For example, one card generates a new armor token when played in stance; however, your opponent must not attack you, otherwise the stance card is discarded and no armor token is gained. Other stance abilities function differently, such as reflect which sends damage back to an attacker; as such, the stance ability only works when a player is attacked.

The dynamics of playing cards in stance contributes to the second abstraction of samurai combat into game mechanic: contemplative strategic play. Stance is one mechanic in Katana where the connection between tactical action and strategic thinking is clear, as cards played do not take effect immediately and require a hybrid tactical-strategic approach. Players must think carefully about what card to play given several factors: their opponent's next move, their opponent's response to whatever card might be played in stance, the player's own short-term goal in this turn, and the longer aim of winning the game. This type of strategic thinking

\footnotetext{
17 Stevenson, "The Warrior in Japanese History," 32. Samurai were more commonly referred to as bushi, or professional warrior, who served under the commander of the emperor's expeditionary forces, the shōgun.

${ }^{18}$ Charles Holcombe, A History of East Asia: From the Origins of Civilization to the Twenty-First Century (New York: Cambridge University Press, 2011), XXX.

${ }^{19}$ Holcombe, A History of East Asia: From the Origins of Civilization to the Twenty-First Century, 152. The term bakufu, used to describe the shōgun administrative regime, means "tent government."
} 
abstracts the psychologically intense and extremely lethal samurai combat into gameplay requiring players to carefully consider every move.

\subsubsection{Representing Shinto and Early Modern Japanese Spirituality in Gameplay}

Shinto is a uniquely Japanese spiritual tradition that occupies space between doctrinal religion and secular philosophy. While the precise definition of Shinto remains slippery-is it a system of beliefs, existential mode of thinking, or simply animistic tradition-no question need be raised as to its essentially Japanese character. ${ }^{20}$ Katana communicates two core components of Shinto practice and belief via game mechanics: veneration of kami, and the dynamics of purification and pollution.

Kami are representations of supernatural power in a variety of forms: animals, plants, people, inanimate objects, mythical beasts, etc. They are beings of both material and spiritual worlds, which affords them unique abilities as semi-divine beings. ${ }^{21}$ Kami are worshipped, although not as saviors and not even as objects of devotion; some kami were historical figures whose infamy incited fear after their death to the extent of motivating supplication. ${ }^{22}$ Katana features 12 distinct kami based on Shinto tradition including Hachiman, patron of warriors, whose popularity among samurai in early modern Japan is noteworthy. Each kami provides a set of passive and active skills related to known characteristics. Hachiman, for example, can augment a player's next attack +3 and allow them to dodge reflected attacks. Fudō Myoō, known as a rage-filled kami, is more of a mixed bag: his powers issue attacks that cannot be reflected, but players may only hold four cards. ${ }^{23}$ Such interpretations reflect the varied personalities and supernatural capabilities of kami venerated by practitioners of Shinto.

Essential to Shinto is the axis of ritual purification and pollution. This basic concept relates the need to purify oneself from polluting forces. ${ }^{24}$ What qualifies as pollution is proximity to taboo, not ill motive or toxic intentionality. Rather, any contact with blood, death, or diseaseno matter the reason-would be deemed polluting. ${ }^{25}$ Purification through water, salts, or ritual fire was the way to cleanse pollution. ${ }^{26}$ Most often, purification was achieved through rinsing with water, as seen in modern Shinto shrines with fountains at the entrance. In Katana, purify cards are the means by which kami skills are activated; that is, they function in a ritual sense, but also as a currency for accessing special powers. Additionally, purification is the only way to dispel pollution applied to your kami by your opponent. Pollution cards are used to destroy a kami-first pollution card disrupts the kami's active skill, second pollution card prevents use of the passive skill, and the third pollution card revokes the kami entirely-whereas purify cards counteract them. In this way, pollution is a matter of external association (forced onto you by

\footnotetext{
${ }^{20}$ Thomas Kasulis, Shinto: The Way Home (Honolulu: University of Hawai'i Press, 2004), 3-4. Kasulis describes Shinto as "a matter of feeling about the world and of feeling one's way through the world." More importantly, he emphasizes the ethnic nature of Shinto. "For many Japanese, 'feeling Shinto' and 'feeling Japanese' are barely distinguishable."

${ }^{21}$ Kasulis, Shinto: The Way Home, 18. "The world as we know it is not separate from the inherent nature of kami."

22 Kasulis, Shinto: The Way Home, 79. Elevation of some infamous individuals posthumously as kami was intended as a preemptive effort at appeasement.

${ }^{23}$ Gabriel Barbier-Mueller, ed., Art of Armor: Samurai Armor from the Ann and Gabriel Barbier-Mueller Museum. (New Haven: Yale University Press, 2012), 136. Fudō Myoō was a bodhisattva syncretized with Shinto to become a patron kami of swordsmen.

${ }^{24}$ Kasulis, Shinto: The Way Home, 50. "The appropriate response to pollution is purification."

${ }^{25}$ Kasulis, Shinto: The Way Home, 48-49. Shinto has a clear taboo on blood and corpses, as well as anything thought to be diseased or generally corrupted. "Blood leaving the body indicates the exit of life energy."

${ }^{26}$ Kasulis, Shinto: The Way Home, 50. Water was most common, whereas fire was usually reserved for corpses.
} 
your opponent) and requires purification to dispel (play a purify card). While Katana simplifies the dynamics of ritual purification and pollution for the sake of gameplay, the mechanics reflect the cultural experience of purity and pollution, and its function as spiritual currency.

\subsection{The Kickstarter Campaign}

Constructing cultural memory requires generating awareness so that people can engage with it. For Katana, it made sense to introduce the public to the game and its goal of forming new cultural memory of early modern Japanese warriors via the Kickstarter platform. Not only does Kickstarter cater to independent creators through its crowdfunding mechanism, but it hosts a community of gaming enthusiasts eager to support innovative projects. Conclusions cannot be made as to the game's reception given the campaign has yet to get underway; come May 30, I will be seeking to raise $\$ 5,000$ to cover the cost of mass producing copies of the game. Nevertheless, the challenge of creating a market-ready product resulted in an improved design. The pressures of cost and consumer expectation have motivated my preparations for the campaign's launch. ${ }^{27}$

\section{Conclusion}

Katana demonstrates the value of interdisciplinary approaches to history. By constructing cultural memory through a synthesis of design and scholarly methodologies, the resulting experience engages players' sense of early modern Japanese warriors in ways not possible through reading a monograph. This is significant for historical discourse in terms of how history is communicated and shared, but also for the tools available to scholars for studying and

27 Begy, "Board Games and the Construction of Cultural Memory," 720. "As material culture...affordability and usability are valued in board games." 
visualizing historical concepts. It also signals a transition for games as an unaccepted form of intellectual expression to evocative of cultural memory far more potent than traditional forms of historical discourse.

While the upcoming Kickstarter campaign will determine commercial interest in the game, it will not prove retention of historical concepts or engagement with cultural memory. Fortunately, my primary goal is not to test retention of historical concepts, but rather to demonstrate that interactivity can be used to engage people with cultural memories. The true limitation is in measuring these attitudes beyond anecdotal assessment, as my playtesting process is entirely qualitative. An opportunity exists to create quantifiable measures by which to gauge efficacy of design and conceptual comprehension.

This and other opportunities to improve the process of constructing cultural memory must be the starting point for future work on interactive historical content. Devising clear standards for assessing design and content in historical games will take on importance as more games are developed in this space. Perhaps a framework for the design of interactive historical games can be crafted, one capable of adjusting to different historical concepts and contexts.

However, such an undertaking is beyond the scope of this project and awaits further study in graduate school and beyond.

For now, my focus remains on Katana in advance of its debut on Kickstarter. While a successful crowdfunding campaign is not guaranteed, what is certain is that the game will contribute to the formation of cultural memory regardless. The challenge for designers and historians is to avoid using history as mere backdrop to trite stories and gameplay, and instead offer contributions that enhance our collective memories and awaken our sense of the past.

\section{Bibliography}

\section{GAME AND PRODUCT DESIGN}

Charsky, Dennis. "From Edutainment to Serious Games: A Change in the Use of Game Characteristics." Games and Culture 5, 2 (2010): 177-198.

Despain, Wendy, ed. 100 Principles of Game Design. NRG. Berkeley: New Riders, 2013. 
Kosa, Mehmet and Murat Yilmaz. "The Design Process of a Board Game for Exploring the Territories of the United States." Press Start 4, 1 (2017): 36-52.

Krug, Steve. Don't Make Me Think, Revisited: A Common-Sense Approach to Web Usability, $3^{\text {rd }}$ ed. San Francisco: Pearson, 2014.

Rouse, Richard. Game Design: Theory \& Practice, $2^{\text {nd }}$ edition. Plano, TX: Wordware, 2004.

Salen, Katie and Eric Zimmerman. Rules of Play: Game Design Fundamentals. Cambridge, MA: MIT Press, 2003.

---. The Game Design Reader: A Rules of Play Anthology. Cambridge, MA: MIT Press, 2006

Schell, Jesse. The Art of Game Design, $2^{\text {nd }}$ edition. Boca Raton: CRC Press, 2015.

Starks, Katryna. "Cognitive Behavioral Game Design: A Unified Model for Designing Serious Games." Frontiers in Psychology 5 (2014): 28.

\section{GAME STUDIES AND LUDOLOGY}

Begy, Jason. "Board Games and the Construction of Cultural Memory." Games and Culture 12, no. 7-8 (November 2017): 718-38.

Caillois, Roger. Man, Play, and Games. Translated by Meyer Barash. Urbana: University of Illinois Press, 2001. Huizinga, Johan. Homo Ludens: A Study of the Play-Element in Culture. Boston: Beacon Press, 1955.

Sicart, Miguel. Play Matters. Cambridge, Massachusetts: MIT Press, 2014.

Von Borries, Friedrich, Steffen P. Walz, Matthias Böttger, Drew Davidson, Heather Kelley, and Julian Kücklich. Space Time Play Computer Games, Architecture and Urbanism: The Next Level. Boston: Birkhauser, 2007.

Wardrip-Fruin, Noah., and Pat Harrigan. Second Person: Role-playing and Story in Games and Playable Media. Cambridge, MA: MIT Press, 2007.

\section{HISTORIOGRAPHY OF EARLY MODERN JAPAN}

Anderson, John. "Kawari Kabuto-Helmets Transformed." In Art of Armor: Samurai Armor from the Ann and Gabriel Barbier-Mueller Museum, 73-75.

Barbier-Mueller, Gabriel, editor. Art of Armor: Samurai Armor from the Ann and Gabriel BarbierMueller Museum. New Haven: Yale University Press, 2012.

Breen, John, and Mark Teeuwen. Shinto in History: Ways of the Kami. Curzon Studies in Asian Religion. Honolulu: University of Hawai'i Press, 2000.

Farris, William Wayne. Heavenly Warriors: The Evolution of Japan's Military, 500-1300. Cambridge, MA: Harvard University Press, 1992.

Hall, John Whitney. "The Muromachi Bakufu." In Yamamura, The Cambridge History of Japan-Volume 3: Medieval Japan, 175-230.

Harris, Victor. Shintō: The Sacred Art of Ancient Japan. London: British Museum, 2001.

Holcombe, Charles. A History of East Asia: From the Origins of Civilization to the Twenty-First Century. New York: Cambridge University Press, 2011.

Howland, Douglas R. "Samurai Status, Class, and Bureaucracy: A Historiographical Essay." The Journal of Asian Studies 60, no. 2 (2001): 353-80.

Keene, Donald. Yoshimasa and the Silver Pavilion: The Creation of the Soul of Japan. Columbia University Press, 2003. 
Mass, Jeffrey P. "The Kamakura Bakufu." In Yamamura, The Cambridge History of Japan-Volume 3: Medieval Japan, 46-88.

Mishima, Yukio. The Way of the Samurai: Yukio Mishima on Hagakure in Modern Life. New York: Basic Books, 1977.

Mulien, Eric. "Bushidō-The Way of the Warrior." In Art of Armor: Samurai Armor from the Ann and Gabriel Barbier-Mueller Museum, 111-117.

Ogawa, Morihiro. "Japanese Armor Deconstructed." In Art of Armor: Samurai Armor from the Ann and Gabriel Barbier-Mueller Museum, 20-25.

Richardson, Thom. "Arms and Armor from the Kofun Period to the Introduction of Firearms." In Art of Armor: Samurai Armor from the Ann and Gabriel Barbier-Mueller Museum, 93-97.

Rizō, Takeuchi. "The Rise of the Warriors," in The Cambridge History of Japan, edited by Donald H. Shively and William H. McCullough (Cambridge: Cambridge University Press, 1999): 644-709.

Ruch, Barbara. "The Other Side of Culture in Medieval Japan." In Yamamura, The Cambridge History of Japan-Volume 3: Medieval Japan, 500-543.

Souyri, Pierre-François. The World Turned Upside Down: Medieval Japanese Society. Translated by Käthe Roth. New York: Columbia University Press, 2001.

Stevenson, John. "The Warrior in Japanese History." In Art of Armor: Samurai Armor from the Ann and Gabriel Barbier-Mueller Museum, 31-49.

Susumu, Ishii. "The Decline of the Kamakura Bakufu." In Yamamura, The Cambridge History of JapanVolume 3: Medieval Japan, 128-74.

Tanaka, Fumon. Samurai Fighting Arts: The Spirit and the Practice. Tokyo: Kondansha, 2003.

Turnbull, Stephen R. The Samurai: A Military History. New York: Macmillan, 1977.

Woodson, Yoko. Lords of the Samurai: The Legacy of a Daimyo Family. San Francisco: Asian Art Museum, 2009.

Yamamura, Kozo, editor. The Cambridge History of Japan-Volume 3: Medieval Japan. Cambridge: Cambridge University Press, 1990.

Yamamoto, Tsunetomo. Hagakure: The Book of the Samurai. Tokyo: Kodansha, 1979. 